Article

\title{
Analysis of Digital Competence for Spanish Teachers at Pre-University Educational Key Stages during COVID-19
}

\author{
Esteban Pérez-Calderón ${ }^{1, * \mathbb{D}}$, Jorge-Manuel Prieto-Ballester ${ }^{2}$ and Vanessa Miguel-Barrado $^{3}$ \\ 1 Faculty of Economics, University of Extremadura, 06006 Badajoz, Spain \\ 2 Faculty of Education, University of La Rioja, 26006 Logroño, Spain; jorgemanuel.prieto@unir.net \\ 3 Faculty of Law, University of Extremadura, 10004 Cáceres, Spain; vmiguel@unex.es \\ * Correspondence: estperez@unex.es; Tel.: +34-696-315-201
}

check for

updates

Citation: Pérez-Calderón, E.;

Prieto-Ballester, J.-M.;

Miguel-Barrado, V. Analysis of

Digital Competence for Spanish

Teachers at Pre-University

Educational Key Stages during

COVID-19. Int. J. Environ. Res. Public

Health 2021, 18, 8093. https://

doi.org/10.3390/ijerph18158093

Academic Editor: Paul B. Tchounwou

Received: 25 June 2021

Accepted: 28 July 2021

Published: 30 July 2021

Publisher's Note: MDPI stays neutral with regard to jurisdictional claims in published maps and institutional affiliations.

Copyright: (C) 2021 by the authors Licensee MDPI, Basel, Switzerland. This article is an open access article distributed under the terms and conditions of the Creative Commons Attribution (CC BY) license (https:/ / creativecommons.org/licenses/by/ $4.0 /)$.

\begin{abstract}
Over time, the role of information and communication technologies (ICT) has become increasingly important in most areas of our lives, including education. So much so, that during the COVID-19 pandemic, the use of these tools has been essential to continue the teaching process. One of the great challenges facing teachers today is their need to adapt to this new educational scenario by acquiring the necessary digital skills. The aim of this study is to determine the level of competence of teaching in pre-university education key stages. To this end, a questionnaire was distributed among education centres and teachers in the Autonomous Community of Extremadura, obtaining 109 valid responses. The analysis methodology was the formation of clusters using the K-means model. The results confirmed that the teachers perceived a medium-high level of knowledge and use of ICT. Moreover, that this digital competence is conditioned by factors such as age, experience, gender, and level of education. In conclusion, public administrations are encouraged to facilitate teachers' knowledge and application of ICT according to the profiles identified.
\end{abstract}

Keywords: pre-university education; COVID-19; digital competence; ICTs

\section{Introduction}

The use of resources based on information and communication technologies (ICT) has changed the way we relate to each other [1], leading to an increase in communication between family and friends [2]. In the labour market, knowledge and competence in the use of ICT are key elements in any type of activity sector. However, only $26 \%$ of organisations are prepared to face the changes brought about by new technologies [3].

These advances in technology have also been slowly transferred to the education system [4], providing teachers with both material and immaterial resources, beyond methodological improvements, which have allowed them to deepen the teaching/learning process, facilitating this work $[5,6]$.

Competence in the use of ICT has been considered a basic skill required of students and so it should also be a fundamental requirement for teachers [7]. Furthermore, teachers are faced with a typology of students who are joining the education system with an increasingly higher skill level of ICT use [8]. Thus, a problem may arise if the people who must lead the teaching/learning process have not experienced the development of ICT at the same level of intensity as their students. Today's teachers cannot be classified as digital natives, but their ICT skills are based on the knowledge that they have had to acquire throughout their working and personal lives.

Thus, many doubts may arise as to whether the level of competence achieved is sufficient for teachers to be able to lead a process in which the real protagonists of their work may have a higher level of skill. In some cases, we even find that, with an adequate level of ICT training, the transition to the implementation of these processes in the teaching environment exposes many gaps within the teaching staff themselves and a lack of confidence in their use [9-12]. 
Additionally, although the use of ICT resources has been considered an important element in the development of teaching for a number of years, recent global events have shown that the use of ICT should be a fundamental requirement for dealing with exceptional situations such as the one being experienced with COVID-19, and which may anticipate in time a change in the paradigm for the educational model conceived to date [13]. This pandemic has meant that teaching has gone from being mostly face-to-face to being virtualised at a rapid pace to all levels of the educational community [14,15]. This obligation to virtualise teaching has revealed many shortcomings that might have been thought to have been overcome and which will surely soon be addressed by the academic world.

It has already become clear that digital competence cannot be seen only as an element that allows access to the use of ICT, but also as a key element of participation today $[16,17]$. Therefore, the justification for studies on the role of ICT in the classroom, which was already sufficient before, has been reinforced with the new crisis caused by the global pandemic, where the virtualisation of teaching has gone from being an option to being the only option.

Internationally, there has been a deep concern that training has moved from the mere transmission of knowledge to the acquisition of skills by students. This concern has been led by institutions themselves [18-23]. There are several models of reference for teachers' digital competences. One of them is the TPACK model. This model integrates technical knowledge, pedagogical knowledge, and the use of ICT to shape meaningful learning [24]. In order to achieve this meaningful learning, it is essential that teachers have sufficient digital competences $[25,26]$. This model enables the appropriate use of technology by teachers, as well as their professional development [26].

Among other models proposed by institutions, those designed by the European Commission and UNESCO can be highlighted [24]. Undoubtedly, the international commitment to the integration of ICT in education has been manifested in different programmes such as DigCompEdu or UNESCO's ICT competences framework [14]. Both models detail ICT competences in teachers, from a European and global perspective, respectively [24]. Thus, the DigCompEdu programme seeks the integration of ICT at all levels of education by addressing pedagogical, technological, and organisational spheres. In order for its implementation to be effective, the different particularities of each educational sector, such as autonomy, research, or innovation, must be taken into account [14]. The framework proposed by UNESCO is a primarily organisational model, focusing on didactic issues and the incorporation of technology into curricula, teacher training, and educational organisation [24]. Furthermore, the development of both frameworks is fully compatible and can complement each other [14].

The current literature highlights the benefits of skills-based learning [19], which has led to it being an extremely important element in curriculum development in Spain in recent years [27], with digital competence being considered one of the basic skills of the education system $[6,17]$. In the previous approach, it is also necessary to consider that technologies are constantly changing, making them obsolete in a very short time. This causes a situation of disorientation for teachers, leading to certain insecurities when it comes to development in ICT environments [28].

ICT is an element that is yet to be exploited at the same level in educational settings as in other social and essential areas, and therefore its scope and growth are still quite broad. There is still a long way to go to achieve adequate initial training for teachers, as well as the professional development that this may entail for them [24].

The use of ICT is not only justified by the intrinsic need that the pandemic has provoked in the education system but also because multiple advantages justify it, such as [29-32]:

- Improves knowledge acquisition.

- $\quad$ Acts as a motivating element.

- Favours autonomous learning.

- $\quad$ Enables the expansion of knowledge. 
- Facilitates participatory methodologies and the development of distant or asynchronous teaching.

The mere fact of the existence of ICT does not change the educational process, instead, it necessary to pay attention to the level, and above all the manner, of its implementation and teacher training for its proper use [24,29]. In order to establish this strategy for the improvement and acquisition of digital skills by teachers, it is essential to know their initial level of these skills [17,33-38].

For all the above reasons, it is important to define a model so that teachers can acquire adequate competence and overcome the gap between their knowledge and the actual implementation of ICT in their teaching methodology [10,39-42]. This study aims to assess the level of teacher digital competence (TDC) in pre-university Spanish education key stages (Educación Secundaria Obligatoria, ESO, equivalent stage to UK years 8-11; Bachillerato, B, and Formación Profesional, FP, equivalent stages to UK years 12-13) using the questionnaire by Tourón et al. [37], validated and based on the competencies established by the NIETTT (National Institute of Educational Technologies and Teacher Training) in the European Union's Common Digital Teaching Framework, to find out how teachers perceive themselves concerning TDC.

In the review of the literature on the subject, it has been found that most studies do not specify the level of TDC of teaching staff at pre-university key stages, which makes studies of this type even more necessary. Therefore, to expand the evidence on the relationship between the knowledge and use of ICT in teaching staff at pre-university educational key stages, one main objective and three specific objectives have been set. The main objective is to ascertain the level of teaching digital competence achieved by pre-university education teaching staff. Parallel to this main objective, we can find other secondary objectives such as: classifying teachers according to their digital competence; identifying training gaps related to the TDC; and proposing educational policies aimed at improving the TDC.

Part of the interest of this work lies in the importance of generating prior knowledge to establish training policies, i.e., to serve as a reference for the design of teacher training policies aimed at identifying the strengths and weaknesses of teachers and redirecting future training in everything related to the improvement of the TDC.

\section{Materials and Methods}

This study is framed within the model established by the European Union (DigComEdu) being applied in Spain through the NIETTT enhancing the pedagogical sphere [24]. This institution has tried to respond to the level of ICT qualifications needed by Spanish teachers in the European reference framework [43].

The present study is quantitative, within a non-experimental design that has not modified any of the study variables initially proposed. It, therefore, aims to achieve the proposed objectives based on the questionnaire validated by Tourón et al. [37]. The initial form is made up of 54 items, grouped into five skill areas, which allow us to find out the vision that teachers at pre-university educational key stages have of their knowledge and application of ICT. The sample consisted of teachers in the Autonomous Community of Extremadura. Convenience sampling was used and participation in the questionnaire was voluntary. A total of 109 valid responses were obtained, of which $43(39.45 \%)$ were men and $66(60.55 \%)$ were women. Table 1 shows the representation by age group, gender, and teaching experience (see Table 1$)$. 
Table 1. Age, gender, and teaching experience of the study participants.

\begin{tabular}{|c|c|c|c|c|c|c|c|}
\hline Age & Gender & Frequency & $\%$ & $\begin{array}{l}\text { Teaching } \\
\text { Experience }\end{array}$ & Gender & Frequency & $\%$ \\
\hline \multirow{2}{*}{ Under 25 years old } & Man & 1 & $0.91 \%$ & \multirow{2}{*}{ Less than 5 years } & Man & 11 & $10.00 \%$ \\
\hline & Woman & 0 & $0.00 \%$ & & Woman & 11 & $10.00 \%$ \\
\hline \multirow{2}{*}{25 to 35} & Man & 4 & $3.64 \%$ & \multirow{2}{*}{ Between 5 and 15} & Man & 15 & $13.64 \%$ \\
\hline & Woman & 2 & $1.82 \%$ & & Woman & 28 & $25.45 \%$ \\
\hline \multirow{2}{*}{35 to 45} & Man & 20 & $18.18 \%$ & \multirow{2}{*}{ Between 15 and 25} & Man & 10 & $9.09 \%$ \\
\hline & Woman & 33 & $30.00 \%$ & & Woman & 11 & $10.00 \%$ \\
\hline \multirow{2}{*}{45 to 55} & Man & 12 & $10.91 \%$ & \multirow{2}{*}{ Between 25 y 35} & Man & 5 & $4.59 \%$ \\
\hline & Woman & 20 & $18.18 \%$ & & Woman & 11 & $10.00 \%$ \\
\hline \multirow{2}{*}{ Over 55 years old } & Man & 6 & $5.50 \%$ & \multirow{2}{*}{ More than 35 years } & Man & 2 & $1.82 \%$ \\
\hline & Woman & 11 & $10.00 \%$ & & Woman & 5 & $4.55 \%$ \\
\hline
\end{tabular}

Source: Authors.

The following tables show the descriptive statistics for the variables used in the study (see Tables 2 and 3).

Table 2. Scale variables.

\begin{tabular}{ccccccccc}
\hline & N & Range & Min & Max & Mean & St. Desv. & Asym. & Kurt. \\
\hline AG & 109 & 36.0 & 31.0 & 67.0 & 45.57 & 8.0489 & 0.478 & -0.442 \\
EX & 109 & 50.0 & 1.0 & 51.0 & 14.69 & 10.9313 & 0.846 & 0.006 \\
\hline Source: Authors.
\end{tabular}

Table 3. Nominal variables.

\begin{tabular}{rccccc}
\hline & Group & Freq. & \% & Asym. & Kurt. \\
\hline \multirow{2}{*}{ SX } & Man & 44 & 40.4 & -0.398 & -1.876 \\
& Woman & 65 & 59.6 & & \\
PR & Badajoz & 83 & 76.1 & 1.244 & -0.461 \\
& Cáceres & 29 & 23.9 & & \\
TC & PF & 14 & $12.8 \%$ & -2.252 & 3.129 \\
& $\mathrm{P}$ & 95 & $87.2 \%$ & & -1.669 \\
LC & $\mathrm{R}$ & 39 & $35.8 \%$ & -0.602 & -1.577 \\
& $\mathrm{U}$ & 70 & $64.2 \%$ & & \\
KS & ESO & 33 & $30.3 \%$ & -0.070 &
\end{tabular}

Source: Authors.

The choice of the questionnaire has been highlighted within the theoretical framework. Without wishing to repeat what has already been justified, it should be noted that this questionnaire has already been validated by a group of experts and tested with 426 teachers [37]. The questions have been grouped according to the area to which they refer to make the responses much simpler; these groupings coincide with the areas of assessment of the TDC.

The variables used to define the teachers' profiles are listed in the Table 4.

Recent studies in the literature have used some of the variables used in this study such as gender, years of experience, and key stage [44,45].

The procedure for collecting responses was carried out through various channels. On the one hand, the questionnaires were sent to high schools so that they could disseminate them among their teaching staff. On the other hand, the questionnaires were disseminated through social networks such as Facebook and Twitter. In addition, the questionnaire was sent to active teachers, with whom we had contact so that they could disseminate it among their acquaintances and colleagues. This phase of questionnaire distribution took place between 20 and 30 May 2020. The questionnaire has been implemented using the Google Forms tool, which allows us to monitor the responses received in Excel format in real-time, to facilitate their download and processing. 
Table 4. Variables.

\begin{tabular}{c}
\hline Age $(A G)$ : teacher's age \\
\hline Gender $(S X)$ : male or female, with the option of not answering \\
\hline Experience $(E X)$ : years of teaching experience \\
Province $(P R):$ Badajoz or Cáceres \\
\hline Type of Centre $(T C)$ : public, P; private or funded, PF \\
\hline Location $(L C)$ : the school is in a rural or urban area \\
\hline Key Stage $(K S):$ ESO, key stage 3-4, years 8-11; BFP, sixth form $7 \mathrm{~A}^{\prime}$ Level
\end{tabular}
Source: Authors.

The methodology applied in this study was a K-means group analysis. Previously, a descriptive analysis and Spearman's correlation analysis were performed.

The data analysis was carried out with the outputs obtained with the SPSS statistical package (v.22).

\section{Results}

In a first approach, for the study of the TDC, a purely descriptive analysis was carried out for each category of items. Beginning with the set of items representing the skills associated with the problem-solving variable (see Table 5), the teachers displayed the highest scores regarding management and storage in the cloud (PST01) and tools for carrying out assessments, tutorials, or monitoring students (PST05), both in terms of knowledge and application of these skills (5.84 and 5.71; 5.14 and 4.94, respectively). The lowest mean score, both in terms of knowledge and use of the skill, was item PST12, corresponding to the forms of peer-to-peer problem solving ( 3.76 and 3.27, respectively).

Table 5. Problem solving tools (PST).

\begin{tabular}{ccccc}
\hline & \multicolumn{2}{c}{ Knowledge } & \multicolumn{2}{c}{ Usage } \\
\hline Item & Mean & St. Desv. & Mean & St. Desv. \\
\hline PST01 (cloud storage) & 5.84 & 1.467 & 5.71 & 1.635 \\
PST02 (use of digital devices) & 4.80 & 1.983 & 4.55 & 2.006 \\
PST03 (diversity in classroom) & 4.07 & 1.849 & 3.63 & 1.829 \\
PST04 (digital competence training) & 4.99 & 1.754 & 4.44 & 1.802 \\
PST05 (evaluation, tutoring, or monitoring) & 5.14 & 1.795 & 4.94 & 1.761 \\
PST06 (computer maintenance) & 4.72 & 2.074 & 4.46 & 2.17 \\
PST07 (incorporation of new devices) & 4.91 & 1.788 & 4.42 & 1.856 \\
PST08 (student digital competency) & 4.73 & 1.804 & 4.43 & 1.791 \\
PST09 (peripheral compatibility) & 4.90 & 2.009 & 4.74 & 2.048 \\
PST10 (digital and non-digital technology) & 4.88 & 1.883 & 4.77 & 1.916 \\
PST11 (educational project adaptation) & 4.44 & 1.880 & 4.15 & 1.873 \\
PST12 (peer-to-peer problems) & 3.76 & 1.865 & 3.27 & 1.934 \\
\hline
\end{tabular}

Source: Authors.

For the set of items associated with tools for accessing and managing information (see Table 6), teachers showed greater knowledge and greater use of strategies for navigating the Internet (INF01: 5.40 and 5.18, respectively). The worst skill, both in terms of knowledge and use, was the item referring to tools for recovering deleted or damaged files or those affected by any formatting problem (INF06: 3.36 and 3.05, respectively). 
Table 6. Information access and management tools (INF).

\begin{tabular}{ccccc}
\hline & \multicolumn{2}{c}{ Knowledge } & \multicolumn{2}{c}{ Usage } \\
\hline Item & Mean & St. Desv. & Mean & St. Desv. \\
\hline INF01 (internet browsing) & 5.40 & 1.617 & 5.18 & 1.634 \\
INF02 (information management) & 4.49 & 2.010 & 4.08 & 2.065 \\
INF03 (didactic videos) & 4.99 & 1.807 & 4.59 & 1.843 \\
INF04 (evaluation of content) & 3.93 & 2.006 & 3.39 & 1.867 \\
INF05 (information in different formats) & 5.09 & 1.747 & 5.00 & 1.838 \\
INF06 (file recovery) & 3.36 & 2.017 & 3.05 & 1.874 \\
INF07 (information sources reliability) & 4.04 & 1.869 & 3.80 & 1.847 \\
\hline
\end{tabular}

Source: Authors.

Of the numerous indicators that make up the variable of teaching competencies for content creation (see Table 7), the high scores for knowledge and use of tools for creating presentations (CCT04: 5.60 and 5.21, respectively) stand out. On the contrary, the low evaluation obtained in the question referring to knowledge and use of tools for content based on augmented reality (CCT05: 2.83 and 2.01, respectively) deserves special mention.

Table 7. Content creation tools (CCT).

\begin{tabular}{ccccc}
\hline & \multicolumn{2}{c}{ Knowledge } & \multicolumn{2}{c}{ Usage } \\
\hline Item & Mean & St. Desv. & Mean & St. Desv. \\
\hline CCT01 (open educational resources) & 4.09 & 1.796 & 3.49 & 1.78 \\
CCT02 (interactive whiteboard) & 4.51 & 1.932 & 3.71 & 1.922 \\
CCT03 (voice recordings) & 4.41 & 2.037 & 3.45 & 2.09 \\
CCT04 (presentations) & 5.60 & 1.588 & 5.21 & 1.67 \\
CCT05 (augmented reality) & 2.83 & 1.851 & 2.01 & 1.426 \\
CCT06 (new products) & 4.82 & 1.919 & 4.10 & 2.027 \\
CCT07 (QR codes) & 4.36 & 2.225 & 3.20 & 2.133 \\
CCT08 (infographics) & 4.76 & 2.017 & 4.22 & 2.000 \\
CCT09 (copyright and licences) & 4.01 & 2.045 & 3.60 & 1.986 \\
CCT10 (evaluation tests) & 4.66 & 1.887 & 4.28 & 1.955 \\
CCT11 (programming) & 3.77 & 2.113 & 3.49 & 2.111 \\
CCT12 (rubrics) & 4.14 & 2.148 & 3.64 & 2.107 \\
CCT13 (types of licences) & 3.83 & 2.309 & 3.19 & 2.223 \\
CCT14 (didactic videos) & 4.54 & 1.907 & 3.96 & 1.928 \\
CCT15 (gamification techniques) & 3.80 & 2.050 & 3.17 & 1.976 \\
CCT16 (content enrichment) & 5.01 & 1.889 & 4.76 & 1.903 \\
\hline
\end{tabular}

Source: Authors.

In the variable representing competence in communication tools, most of the responses reported a medium-high rating. Respondents expressed a high valuation in the knowledge and use of online communication tools, such as forums, video calls, or instant messaging (see Table 8, COM03: 5.80 and 5.56, respectively). In the second place, in terms of knowledge and use, were tools associated with the communication of grades and the evaluation of assignments or tutorials (COM02: 5.69 and 5.50, respectively). In this category, the high level of knowledge developed by teachers concerning the use of social networks such as Facebook or Twitter (COM05) stands out. Finally, the lowest knowledge scores were achieved for the tools regarding the management of digital identities in the educational context (COM06). 
Table 8. Communication tools (COM).

\begin{tabular}{ccccc}
\hline & \multicolumn{2}{c}{ Knowledge } & \multicolumn{2}{c}{ Usage } \\
\hline Item & Mean & St. Desv. & Mean & St. Desv. \\
\hline COM01 (digital technology projects) & 4.80 & 1.942 & 4.31 & 2.025 \\
COM02 (software at school) & 5.69 & 1.575 & 5.50 & 1.632 \\
COM03 (online communication) & 5.80 & 1.532 & 5.56 & 1.624 \\
COM04 (behaviour and etiquette) & 4.74 & 1.921 & 4.61 & 1.925 \\
COM05 (social networks) & 5.68 & 1.677 & 3.22 & 1.889 \\
COM06 (digital identity management) & 3.69 & 1.961 & 4.01 & 1.949 \\
COM07 (experiences and & 4.34 & 1.820 & 4.05 & 2.174 \\
educational research) & 4.73 & 2.100 & 5.15 & 1.854 \\
COM08 (collaborative learning) & & & &
\end{tabular}

Source: Authors.

In the category referring to tools related to safety and the proper use of technology, Table 9 shows how the highest level of knowledge and use referred to systems for accessing and protecting devices or documents (SAF01: 5.02 and 4.85, respectively). The rest of the items reported a medium-high valuation, with the aspect referring to knowledge and use of means of control between technology and student distraction obtaining the lowest score (SAF08: 3.58 and 3.23, respectively).

Table 9. Tools associated with safety (SAF).

\begin{tabular}{ccccc}
\hline & \multicolumn{2}{c}{ Knowledge } & \multicolumn{2}{c}{ Usage } \\
\hline Item & Mean & St. Desv. & Mean & St. Desv. \\
\hline SAF01 (device/document protection) & 5.02 & 1.839 & 4.85 & 1.906 \\
SAF02 (technological recycling) & 4.50 & 1.986 & 4.08 & 2.046 \\
SAF03 (data removal) & 4.44 & 2.104 & 4.15 & 2.151 \\
SAF04 (virus threat protection) & 4.50 & 2.067 & 4.43 & 2.137 \\
SAF05 (rules on responsible use) & 4.81 & 1.779 & 4.50 & 1.84 \\
SAF06 (protection of information) & 4.33 & 2.109 & 4.17 & 2.106 \\
SAF07 (basic energy saving) & 4.70 & 2.058 & 4.43 & 1.958 \\
SAF08 (control distracting modes) & 3.58 & 1.83 & 3.23 & 1.707 \\
\hline Source
\end{tabular}

Source: Authors.

As an extension of the descriptive analysis, the results obtained in the Spearman correlation analysis showed a positive and highly significant association for most of the items between the variables age and experience (see Appendix B, Tables A1-A16). In particular, for the categories of ICT tools including problem solving, content creation, information access and management, and communication. The female gender is also associated with lower levels of some digital skills, especially in the case of problem solving (see Tables A7 and A12), information access and management (more in knowledge than in use, see Table A8), safety (more in knowledge than in use, see Table A11), and communication (more in knowledge than in use, see Table A11).

In addition to the previous descriptive study, a K-means cluster analysis was performed to classify the data according to the variances observed in the responses. Thanks to this method, homogeneous groups were obtained in which to observe characteristics and define different teacher profiles according to their knowledge and use of ICT skills. The method also ensures the maximum difference between the variances between the groups formed. In our case, checking the result of the ANOVA analysis, all the items are significant $(p$ value $<0.01)$ in their contribution to the definition of the group in which they are classified (see Appendix C, Tables A12-A16). This is because we have worked with a refined and contrasted model in previous studies [37]. When setting the number of groupings, the dendrogram was used as a reference once the responses were classified in the different items for each competence category and according to Ward's method. 
Beginning with the category referring to knowledge of communication tools (K_COM), Table 10 shows that two well-differentiated groups were obtained. In one of them, almost $75 \%$ of the total are classified as showing a high use of these tools (5.56 out of 7). The rest show a clear deficiency with an average rating of 3 out of 7 . In the first case, these are teachers with an average age and experience of 43.63 and 12.43 years, respectively. Age seems to be a determining factor in the knowledge of these tools, with those over 50.64 years of age being the least knowledgeable. Women show a higher level of knowledge, representing $54.3 \%$ within the highest scoring group. By type of school, most of the teachers with the highest level of knowledge work in public schools and urban environments $(87.7 \%$ and $60.5 \%$, respectively). Additionally, higher educational stages (sixth form $7 \mathrm{~A}^{\prime}$ Level) bring together a greater number of teachers with greater knowledge of these tools $(66.7 \%)$.

Table 10. Cluster groups as regards the knowledge and use of communication tools (COM).

\begin{tabular}{cccccc}
\hline & K-G1 & K-G2 & U-G1 & UG2 & U-G3 \\
\hline Frequency & $25.69 \%$ & $74.31 \%$ & $35.78 \%$ & $40.37 \%$ & $23.85 \%$ \\
Means & 3.00 & 5.56 & 3.00 & 5.78 & 4.78 \\
$A G$ & 50.64 & 43.63 & 48.77 & 42.27 & 45.77 \\
$E X$ & 21.21 & 12.43 & 18.79 & 11.09 & 14.62 \\
$S X(\mathrm{M}, \mathrm{W})$ & $25 \%, 75 \%$ & $45.7 \%, 54.3 \%$ & $33.3 \% 66.7 \%$ & $40.9 \%, 59.1 \%$ & $50 \%, 50 \%$ \\
$P R(\mathrm{~B}, \mathrm{C})$ & $82.1 \%, 17.9 \%$ & $74.1 \%, 25.9 \%$ & $84.6 \%, 15.4 \%$ & $77.3 \%, 22.7 \%$ & $61.5 \%, 38.5 \%$ \\
TC (PF, P) & $14.3 \%, 85.7 \%$ & $12.3 \%, 87.7 \%$ & $12.8 \%, 87.2 \%$ & $15.9 \%, 84.1 \%$ & $7.7 \%, 92.3 \%$ \\
LC (R, U) & $25 \%, 75 \%$ & $39.5 \%, 60.5 \%$ & $35.9 \%, 64.1 \%$ & $40.9 \%, 59.1 \%$ & $26.9 \%, 73.1 \%$ \\
KS (BFP, ESO) & $78.5 \%, 21.4 \%$ & $66.7 \%, 33.3 \%$ & $76.9 \%, 23.1 \%$ & $56.8 \%, 43.2 \%$ & $80.8 \%, 19.2 \%$ \\
\hline Source: Authors. & & & & &
\end{tabular}

According to the teachers' declared use of ICT communication tools, three groups (U-COM) were obtained. As can be seen in Table 10, the level of use is lower than the declared level of knowledge. In one of these groups are teachers who have declared a lower level of use of these tools, $35 \%$ of those surveyed, obtaining an average score of 3 out of a maximum of 7 . The profile of the teachers who reported a lower use of these types of tools corresponds to teachers of older age and average experience; they are teachers who teach at the highest educational level, i.e., years 12-13, and the proportion of women is higher $(66.7 \%)$. The rest of the teachers achieve a notable rating. In one of the two groups with the highest levels of knowledge, there are deficiencies related to the management of digital identities, the sharing of experiences or educational research of other colleagues, and tools for collaborative learning (see Table 10).

Analysing the content creation group, in terms of teachers' knowledge (K-CCT), two well-differentiated groups were obtained (see Table 11). In one of the groups, with a representation of $36.7 \%$, the teachers failed (2.56). This group has a higher average age, while the other group has a notable level of knowledge (5.31). Once again, age conditions ICT knowledge. The group with the lowest scores is made up mostly of women, teachers in urban and public schools, and at higher educational stages, as opposed to those who teach ESO (years 8-11). Within the group of teachers who best value their knowledge, a more uniform number of cases can be observed according to gender, school type (rural/urban), or educational stages. However, the province of Badajoz and public schools are those with the highest number of teachers in this group.

A similar result was obtained in the category referring to the use of this type of tool (U-CCT, see Table 11), with younger teachers reporting greater use compared to teachers with a higher average age, even though these teachers have more experience. Although three groups were obtained, one of them can be discarded since it was formed by a single teacher who can be considered an atypical case for the rest. The group with the highest number of teachers is the one that fails in the use of this type of ICT $(58.72 \%)$, with women, teachers in public and urban schools, and at higher educational stages (years 13-14) highlighted. In the group with the highest scores, the public ownership of the schools $(86.4 \%)$ and higher key stages $(59 \%)$ stand out. 
Table 11. Cluster groups as regards the knowledge and use of content creation tools (CCT).

\begin{tabular}{ccccc}
\hline & K-G1 & K-G2 & U-G1 & U-G2 \\
\hline Frequency & $36.70 \%$ & $63.30 \%$ & $41.28 \%$ & $58.72 \%$ \\
Means & 2.56 & 5.31 & 5.06 & 2.69 \\
$A G$ & 48.65 & 43.56 & 43.43 & 46.66 \\
$E X$ & 18.3 & 12.59 & 12.48 & 16.28 \\
$S X(\mathrm{M}, \mathrm{W})$ & $32.5 \%, 67.5 \%$ & $44.9 \%, 55.1 \%$ & $45.5 \%, 54.5 \%$ & $37.5 \%, 62.5 \%$ \\
$P R(\mathrm{~B}, \mathrm{C})$ & $87.5 \%, 12.5 \%$ & $69.6 \%, 30.4 \%$ & $75 \%, 25 \%$ & $76.6 \%, 23.4 \%$ \\
$T C(\mathrm{PF}, \mathrm{P})$ & $12.5 \%, 87.5 \%$ & $13 \%, 87 \%$ & $13.6 \%, 86.4 \%$ & $12.5 \%, 87.5 \%$ \\
LC (R, U) & $32.5 \%, 67.5 \%$ & $37.7 \%, 62.3 \%$ & $40.9 \%, 59.1 \%$ & $32.8 \%, 67.2 \%$ \\
KS (BFP, ESO) & $75 \%, 25 \%$ & $66.7 \%, 33.3 \%$ & $59.1 \%, 40.9 \%$ & $76.6 \%, 23.4 \%$ \\
\hline
\end{tabular}

Source: Authors.

Analysing the characteristics of the groups trained in the knowledge of tools for information access and management (K-INF, see Table 12), the data referring to age and years of experience are significant, with teachers with a lower average age and fewer years of experience (42.86 and 11.42 years, respectively) having the greatest knowledge of information access and management tools. The two groups with the highest reported knowledge account for more than $80 \%$ of the respondents. Conversely, those with older age and with more years of experience on average (50.35 and 19.8, respectively) report poor knowledge. Among the teachers with the least knowledge of these information resources, it is noteworthy that the vast majority are women (80\%). In addition, the data show that teachers who teach in public schools, in urban areas, and in the Baccalaureate and Vocational Training field are those who have least valued their knowledge in this area $(85 \%, 70 \%$, and $85 \%$, respectively).

Table 12. Cluster groups as regards the knowledge and use of information access and management tools. (INF).

\begin{tabular}{|c|c|c|c|c|c|c|}
\hline & K-G1 & K-G2 & K-G3 & U-G1 & U-G2 & U-G3 \\
\hline Frequency & $18.35 \%$ & $38.53 \%$ & $43.12 \%$ & $37.62 \%$ & $33.95 \%$ & $28.44 \%$ \\
\hline Means & 2 & 6 & 4 & 5.43 & 2.57 & 4.29 \\
\hline$A G$ & 50.35 & 42.86 & 45.64 & 43.44 & 47.51 & 45.58 \\
\hline$E X$ & 19.8 & 11.43 & 15.43 & 12.78 & 16.84 & 14.65 \\
\hline$S X(\mathrm{M}, \mathrm{W})$ & $20 \% .80 \%$ & $50 \%, 50 \%$ & $40.4 \%, 59.6 \%$ & $46.3 \%, 53.7 \%$ & $27 \%, 73 \%$ & $48.4 \%, 51.6 \%$ \\
\hline$P R(B, C)$ & $95 \%, 5 \%$ & $78.6 \%, 21.4 \%$ & $66 \%, 34 \%$ & $78 \%, 22 \%$ & $73 \%, 27 \%$ & $77.4 \%, 22.6 \%$ \\
\hline$T C(\mathrm{PF}, \mathrm{P})$ & $15 \%, 85 \%$ & $14.3 \%, 85.7 \%$ & $10.6 \%, 89.4 \%$ & $14.6 \%, 85.4 \%$ & $16.2 \%, 83.8 \%$ & $6.5 \%, 93.5 \%$ \\
\hline$L C(\mathrm{R}, \mathrm{U})$ & $30 \%, 70 \%$ & $35.7 \%, 64.3 \%$ & $38.3 \%, 61.7 \%$ & $36.6 \%, 63.4 \%$ & $32.4 \%, 67.6 \%$ & $38.7 \%, 61.3 \%$ \\
\hline$K S(\mathrm{BFP}, \mathrm{ESO})$ & $85 \%, 15 \%$ & $64.3 \%, 35.7 \%$ & $67.1 \%, 31.9 \%$ & $63.4 \%, 36.6 \%$ & $70.2 \%, 29.7 \%$ & $77.4 \%, 22.6 \%$ \\
\hline
\end{tabular}

Source: Authors.

In the category referring to the use of these tools, the results show a significant difference in terms of the average age and experience of the respondents. Younger teachers and those with fewer years of experience ( 43.44 and 12.78 , respectively) use these resources more. Older and more experienced teachers (47.51 and 16.84, respectively) reported less use. Additionally, within this group of teachers, the high percentage of women (73\%) stands out. In addition, the results contrast with the fact that the educational level at which these tools have been used the least was in public schools and BFP, years $12-13(83.8 \%$ and $70.2 \%$, respectively).

In the table showing the results referring to knowledge in safety issues (see Table 13), the youngest teachers and those with the least years of experience (43.57 and 12.39, respectively) are the ones with the highest knowledge in this area. This group with the highest rating accounts for $62.38 \%$, while those who are older and have been working for more years are, on average, rated their knowledge of these skills the lowest (48.51 and 18.48, respectively). Another relevant aspect is the high percentage of women among the teachers with the least knowledge of safety $(73.2 \%)$; as are teachers in public and urban schools and at BFP $(85.4 \%, 68.3 \%$, and $75.6 \%$, respectively). On the other hand, most of the teachers 
with the most knowledge, $62.38 \%$, teach at the highest levels and in public and urban schools ( $85.7 \%$ and $64.3 \%$, respectively).

Table 13. Cluster groups as regards the knowledge and use of safety tools (SAF).

\begin{tabular}{ccccc}
\hline & K-G1 & K-G2 & U-G1 & U-G2 \\
\hline Frequency & $37.62 \%$ & $62.38 \%$ & $38.53 \%$ & $61.47 \%$ \\
Means & 2.63 & 5.63 & 2.50 & 5.12 \\
$A G$ & 48.51 & 43.57 & 48.6 & 43.45 \\
$E X$ & 18.49 & 12.4 & 18.57 & 12.25 \\
$S X(\mathrm{M}, \mathrm{W})$ & $26.8 \%, 73.2 \%$ & $48.5 \%, 51.5 \%$ & $28.6 \%, 71.4 \%$ & $47.8 \%, 52.2 \%$ \\
$P R(\mathrm{~B}, \mathrm{C})$ & $78 \%, 22 \%$ & $75 \%, 25 \%$ & $76.2 \%, 23.8 \%$ & $76.1 \%, 23.9 \%$ \\
TC $(\mathrm{PF}, \mathrm{P})$ & $14.6 \%, 85.4 \%$ & $11.8 \%, 88.2 \%$ & $16.7 \%, 83.3 \%$ & $10.4 \%, 89.6 \%$ \\
LC (R, U) & $31.7 \%, 68.3 \%$ & $38.2 \%, 61.8 \%$ & $33.3 \%, 66.7 \%$ & $37.3 \%, 62.7 \%$ \\
KS (BFP, ESO) & $75.6 \%, 24.4 \%$ & $66.1 \%, 33.8 \%$ & $73.8 \%, 26.2 \%$ & $67.2 \%, 32.8 \%$ \\
\hline Source: Authors. & & & &
\end{tabular}

Source: Authors.

In the cluster referring to the use of safety tools (see Table 13), it can be observed that the average age and years of practice differ quite a bit, with the age and years of experience being lower in the most qualified teachers ( 43.45 and 12.25 , respectively) for the teachers who have made the least use of them (48.6 and 18.57, respectively). In addition, there is an important difference within the teachers who have used these tools the least in terms of gender, with the percentage of women being considerably higher $(71.4 \%)$, mostly in public, urban, and BFP $(83.3 \%, 66.7 \%$, and $73.8 \%$, respectively).

The teachers with the greatest knowledge of problem solving (K-PST, see Table 14) stand out for their younger age and years of average experience (43.23 and 12.02, respectively), while those with the least knowledge in this regard are older and have more years of professional experience (50.72 and 21.09, respectively). It should be noted that the group with the best assessment is the largest, accounting for $70.64 \%$ of the total. It is also important to note that most of the teachers with the least knowledge are women (75\%), as well as teachers in public, urban, and last educational years $(87.5 \%, 71.9 \%$, and $78.2 \%$, respectively). In addition, the data show that the highest percentage of teachers with high knowledge coincides with the profile of the group with the lowest qualification level.

Again, looking at the statements of use of ICT and problem solving skills, Table 14 shows that teachers with lower average age and professional trajectory are those who have made more use of these problem solving tools (43.69 and 12.33, respectively), to the detriment of those who are older and more experienced (48.56 and 18.92, respectively). The largest group, $70.64 \%$, is formed by those with the best knowledge. Again, within the group with greater deficiencies, women, teachers in public and urban schools, and at higher key stages make up the majority $(74.4 \%, 84.6 \%, 69.2 \%$, and $71.8 \%$, respectively).

Table 14. Cluster groups as regards the knowledge and use of problem solving tools (PST).

\begin{tabular}{ccccc}
\hline & K-G1 & K-G2 & U-G1 & U-G2 \\
\hline Frequency & $29.36 \%$ & $70.64 \%$ & $35.78 \%$ & $64.22 \%$ \\
Means & 2.67 & 5.67 & 2.75 & 5.25 \\
$A G$ & 50.72 & 43.23 & 48.56 & 43.69 \\
$E X$ & 21.09 & 12.02 & 18.92 & 12.33 \\
$S X(\mathrm{M}, \mathrm{W})$ & $25 \%, 75 \%$ & $46.8 \%, 53.2 \%$ & $25.6 \%, 74.4 \%$ & $48.6 \%, 51.4 \%$ \\
$P R(\mathrm{~B}, \mathrm{C})$ & $84.4 \%, 15.6 \%$ & $72.7 \%, 27.3 \%$ & $76.9 \%, 23.1 \%$ & $75.7 \%, 24.3 \%$ \\
$T C(\mathrm{PF}, \mathrm{P})$ & $12.5 \%, 87.5 \%$ & $13 \%, 87 \%$ & $15.4 \%, 84.6 \%$ & $11.4 \%, 88.6 \%$ \\
LC $(\mathrm{R}, \mathrm{U})$ & $28.1 \%, 71.9 \%$ & $39 \%, 61 \%$ & $30.8 \%, 69.2 \%$ & $38.6 \%, 61.4 \%$ \\
KS (BFP, ESO) & $78.2 \%, 21.9 \%$ & $66.3 \%, 33.8 \%$ & $71.8 \%, 28.2 \%$ & $68.6 \%, 31.4 \%$ \\
\hline
\end{tabular}

Source: Authors. 


\section{Conclusions}

The study analyses the level of TDC in pre-university teachers (secondary school, years 8-13). Evaluations of indicators associated with the use and knowledge of five dimensions of ICT have been analysed: problem-solving, access and management of information, content creation, communication tools, and safety.

According to the results of the analysis, teachers at these educational levels are not only familiar, but also use tools to make presentations of their content. In addition, tools for cloud management, Internet browsing, synchronous/asynchronous virtual communication, or protection of devices and documents are the skills with which teachers are valued to a greater extent, both in their knowledge and in their use. On the other hand, for peer problem solving, recovery of deleted material, technology control, and student distraction, the lowest ratings were observed and, therefore, there is greater room for improvement, both in terms of knowledge and use. A deficit was detected for content creation tools based on augmented reality, since it is a novel resource and requires a high level of training to generate the necessary skills, this state of affairs having been highlighted before in previous work [42]. It is surprising that teachers express a high level of use of social networks and yet have no knowledge of how to use them in their profession. Undoubtedly, action is needed in this area since they are communication channels used extensively by students in their social activities and their use in education can be a motivation because they are tools that they already master.

Likewise, it has been observed that ICT knowledge and use are conditioned by factors such as age, gender, years of experience, or educational stage. In line with previous studies, digital competence is higher in younger teachers [46,47]. In line with other studies [48,49], a significant difference in terms of gender has been observed within the groups of teachers, with women generally being less skilled in digital competencies and how to use them. Furthermore, according to recent studies [50], the results obtained show that the educational level at which teaching is provided is a factor that has an impact on the level of digital competence of the teachers.

We can conclude that teachers consider that they have an intermediate-high level of knowledge and use of the tools that define their TDC. This good level of knowledge and use has had an impact on their rapid adaptation to the demands of the new educational environment in the worst moments of the SARS-Cov-2 pandemic. In line with the above, the high level of ICT use associated with leisure, relationships, and personal communication has facilitated the use of those ICTs used in the development of their profession as teachers, although further training in the use of these tools in these educational stages is still pending.

It is essential to objectively evaluate the extent to which ICTs have made inroads in education. Therefore, in addition to evaluating the knowledge and use of ICT by teachers, it would be interesting to assess whether this application is carried out from a constructivist point of view and not as a mere instrument within the teaching-learning process.

In addition, one of the key elements that must be considered in the study of teachers' digital competence is motivation. As in other areas of teacher training, historically, teachers have not had a real motivation for continuous training [24,51]. There are major shortcomings in the motivation for teacher training, and in the field of ICT, generating teacher burnout in the transition from face-to-face to virtual teaching [52]. The COVID-19 pandemic, in which teachers have had to adapt in a short time, and with great effort, to ICT tools for didactic use [53], has led to greater teacher burnout [52].

Other studies analyse contextual facilitators for learning activities using ICT [54]. These perspectives are very interesting to consider in any study of teachers' digital competences. This would undoubtedly be another limitation of our study and future work would need to consider the complex dynamics of the factors that condition the success of digital teaching. Similarly, it would be interesting to include other factors associated with the digital resources of centres, the day-to-day technical support that teachers have at their workplace, the digital equipment of students, and other institutional, organisational, and administrative factors [54]. 
In the same vein, public administrations must be motivated to a greater extent to carry out a real development in the use and application of ICTs by teachers. To this end, it is essential that, in addition to the technical means, teachers are provided with training and sufficient time to practice, choose, and develop the most appropriate content for their subject and educational level. Thus, we propose the development of comprehensive, collaborative training plans, open over time, allowing the progressive process of acquisition of digital skills adapted to the specific needs of teachers, schools, and students. It is essential to have teaching staff trained in this way so that they can convey this knowledge to students, making them competent in this area and thus enabling them to make proper use of technology, something of an extreme necessity nowadays.

Finally, the findings from this study indicate that this subject requires further research. Although this study has been carried out on teachers in Extremadura, the findings may give insight into the situation at the Spanish level, as teacher training policies tend to be very similar between the different Autonomous Communities, especially in the field of ICT, where there is a body such as the NIETTT in charge of ICT integration in the educational stages prior to university. This institute is also in charge of ICT training, which means that all teachers, regardless of their place of residence, have the same possibilities to acquire digital competence. As this study has only been carried out on a limited sample, it cannot be regarded as representative of teachers either within the entire Autonomous Community of Extremadura or on a national level, thus, the findings obtained cannot be extrapolated and future studies should be conducted on larger samples.

In addition, another possible improvement could be to study other educational levels, such as infant and primary education, to develop preventive measures in ICT training so that teachers could anticipate students' ICT skills before they reach the pre-university educational key stages. Finally, the number of items ought to be increased, to include a variable referring to the satisfaction or global self-perception that would allow us to elaborate a more complex analysis of the data using the structural equation technique.

Author Contributions: Conceptualization, V.M.-B. and J.-M.P.-B.; methodology, E.P.-C. and V.M.-B.; software, E.P.-C.; validation, E.P.-C.; data collection and treatment, J.-M.P.-B. and V.M.-B.; preparation of the original draft of the manuscript, J.-M.P.-B. and E.P.-C.; review and editing of the manuscript, E.P.-C.; supervision, E.P.-C. All authors have read and agreed to the published version of the manuscript.

Funding: This research was funded by European Regional Development Fund, European Union "A way of making Europe", and by Council of Economy and Infrastructure, Regional Government of Extremadura (Spain), grant number GR18128.

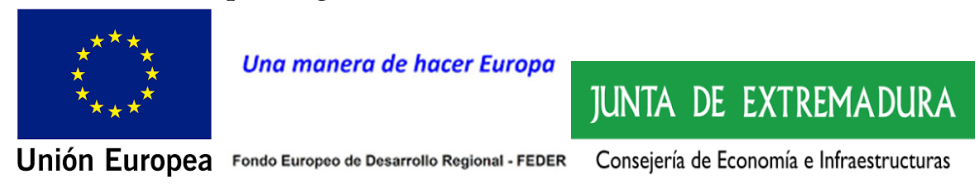

Institutional Review Board Statement: Ethical review and approval were waived for this study because it was non-interventional. Confidentiality was maintained by responses being completely anonymous and only aggregated data are presented.

Informed Consent Statement: Informed consent was obtained from all subjects involved in the study.

Data Availability Statement: Not applicable.

Conflicts of Interest: The authors declare no conflict of interest. 
Appendix A. Questionnaire. Items Groups

\begin{tabular}{|c|c|}
\hline & COMMUNICATION TOOLS \\
\hline COM01 & Projects at my school related to digital technologies \\
\hline COM02 & $\begin{array}{l}\text { Software available in my school (grades, attendance, communication with } \\
\text { family, contents, homework evaluation, etc.). }\end{array}$ \\
\hline COM03 & $\begin{array}{c}\text { Tools for online communication: forums, instant messaging, } \\
\text { chats, videoconferencing ... }\end{array}$ \\
\hline COM04 & $\begin{array}{l}\text { Basic rules of behaviour and etiquette in online communication in the } \\
\text { educational context. }\end{array}$ \\
\hline COM05 & $\begin{array}{l}\text { Social networks or learning communities for sharing information and } \\
\text { educational content (e.g., Facebook, Twitter, Google+, or others). }\end{array}$ \\
\hline COM06 & Forms of digital identity management in the educational context. \\
\hline $\mathrm{COM} 07$ & $\begin{array}{c}\text { Experiences or educational research of others that can provide me with } \\
\text { content, ideas, strategies, for my teaching. }\end{array}$ \\
\hline COM08 & $\begin{array}{c}\text { Tools for shared or collaborative learning (e.g., blogs, wikis, specific } \\
\text { platforms such as Edmodo or others). } \\
\text { CONTENT CREATION TOOLS }\end{array}$ \\
\hline ССТ01 & Open educational resources (OERs). \\
\hline ССТ02 & The software of the interactive whiteboard of my school. \\
\hline ССТ03 & Tools to create voice recordings (podcast). \\
\hline ССТ04 & Tools for creating presentations. \\
\hline ССТ05 & Tools for content based on augmented reality. \\
\hline ССТ06 & $\begin{array}{l}\text { The potential of ICTs to program and create new products (tools, } \\
\text { Apps, contents ... ) }\end{array}$ \\
\hline ССТ07 & Tools to produce QR codes (Quick Response). \\
\hline ССТ08 & $\begin{array}{l}\text { Tools to facilitate learning such as: infographics, interactive graphics, } \\
\text { concept maps, timelines, etc. }\end{array}$ \\
\hline ССТ09 & Sources for locating copyright regulations and licenses of use. \\
\hline CCT10 & Tools to develop evaluation tests. \\
\hline CCT11 & $\begin{array}{l}\text { The basic logic of programming, understanding its structure and simple } \\
\text { modification of digital devices and their configuration. }\end{array}$ \\
\hline CCT12 & Tools for developing rubrics. \\
\hline CCT13 & $\begin{array}{c}\text { Different types of licenses to publish my content (copyright, copy left and } \\
\text { creative commons). }\end{array}$ \\
\hline CCT14 & Tools for the creation of didactic videos. \\
\hline CCT15 & Tools that help to use gamification techniques in the learning process. \\
\hline CCT16 & $\begin{array}{l}\text { Tools for reworking or enriching content in different formats (e.g., texts, } \\
\text { tables, audio, images, videos, etc.). }\end{array}$ \\
\hline INF01 & $\begin{array}{l}\text { INFORMATION ACCESS AND MANAGEMENT TOOLS } \\
\text { Internet browsing strategies (e.g., searching, filtering, use of operators, } \\
\text { specific commands, use of search operators, etc.). }\end{array}$ \\
\hline INF02 & $\begin{array}{c}\text { Information management strategies (use of bookmarks, information } \\
\text { retrieval, classification, etc.). }\end{array}$ \\
\hline INF03 & Specific channels for the selection of didactic videos. \\
\hline INF04 & $\begin{array}{l}\text { Rules or criteria to critically evaluate the content of a website (updates, } \\
\text { citations, sources, etc.). }\end{array}$ \\
\hline INF05 & $\begin{array}{l}\text { Strategies for searching, locating, and selecting information in different } \\
\text { media or formats (text, video, etc.). }\end{array}$ \\
\hline INF06 & Tools for recovering deleted, damaged, inaccessible, or formatted files, etc. \\
\hline INF07 & $\begin{array}{c}\text { Criteria for assessing the reliability of information sources, data, digital } \\
\text { content, etc. }\end{array}$ \\
\hline
\end{tabular}




\begin{tabular}{|c|c|}
\hline & PROBLEM SOLVING TOOLS \\
\hline PST01 & $\begin{array}{l}\text { Solutions for management and storage in the "cloud", file sharing, } \\
\text { granting access privileges, etc. (e.g., Drive, OneDrive, dropbox, or others). }\end{array}$ \\
\hline PST02 & $\begin{array}{l}\text { Basic solutions to technical problems arising from the use of digital devices } \\
\text { in the classroom. }\end{array}$ \\
\hline PST03 & Tools to help address diversity in the classroom. \\
\hline PST04 & Spaces for training and updating my digital competence. \\
\hline PST05 & Tools to carry out evaluation, tutoring, or monitoring of students. \\
\hline PST06 & $\begin{array}{l}\text { Basic computer maintenance tasks to avoid possible malfunctions (e.g., } \\
\text { updates, cache, or disk cleaning, etc.). }\end{array}$ \\
\hline PST07 & $\begin{array}{l}\text { Ways to update myself and incorporate new devices, apps, or tools } \\
\text { in my work. }\end{array}$ \\
\hline PST08 & Creative didactic activities to develop digital competence in students. \\
\hline PST09 & $\begin{array}{c}\text { Compatibility of peripherals (microphones, headsets, printers, etc.) and } \\
\text { their connectivity requirements. }\end{array}$ \\
\hline PST10 & $\begin{array}{l}\text { Options for combining digital and non-digital technology to find solutions } \\
\text { in the teaching-learning process. }\end{array}$ \\
\hline PST11 & Digital resources adapted to the centre's educational project. \\
\hline PST12 & $\begin{array}{l}\text { Peer-to-peer problem solving. } \\
\text { SAFETY TOOLS }\end{array}$ \\
\hline SAF01 & $\begin{array}{l}\text { Device or document protection system (access control, privileges, } \\
\text { passwords, etc.). }\end{array}$ \\
\hline SAF02 & $\begin{array}{l}\text { Recycling points to reduce the impact of technological debris on the } \\
\text { environment (unused devices, cell phones, printer toner, batteries, etc.). }\end{array}$ \\
\hline SAF03 & $\begin{array}{c}\text { Ways to remove data/information, when necessary, that you are } \\
\text { responsible for about yourself or others. }\end{array}$ \\
\hline SAF04 & Protection from virus threats, malware, etc., for devices. \\
\hline SAF05 & Rules on the responsible and healthy use of digital technologies. \\
\hline SAF06 & $\begin{array}{c}\text { Protection of information (names, images, etc.) relating to people in your } \\
\text { immediate environment (classmates, students, etc.). }\end{array}$ \\
\hline SAF07 & Basic energy saving measures. \\
\hline SAF08 & Ways to control distracting modes of use of technology. \\
\hline
\end{tabular}

\section{Appendix B. Spearman Correlation Matrices}

Table A1. Spearman correlation matrix.

\begin{tabular}{cccccccc}
\hline & SX & AG & PR & TC & LC & EX & KS \\
\hline$S X$ & & & & & & & \\
$A G$ & 0.016 & & & & & & \\
$P R$ & 0.153 & -0.125 & & & & & \\
$T C$ & 0.131 & 0.043 & 0.022 & & & & \\
$L C$ & 0.088 & 0.035 & -0.031 & $-0.229 *$ & & & \\
$E X$ & 0.053 & $0.753^{* *}$ & -0.117 & 0.100 & 0.089 & \\
$K S$ & -0.076 & -0.105 & -0.026 & 0.182 & 0.034 & -0.162 & \\
\hline
\end{tabular}

Source: Authors. $p$ value: ${ }^{* *}<0.05 ;^{*}<0.10$.

Table A2. Spearman correlation matrix: knowledge of problem solving tools.

\begin{tabular}{|c|c|c|c|c|c|c|c|c|c|c|c|c|}
\hline & PST01 & PST02 & PST03 & PST04 & PST05 & PST06 & PST07 & PST08 & PST09 & PST10 & PST11 & PST12 \\
\hline$S X$ & -0.075 & -0.180 & 0.022 & -0.210 * & $-0.204 *$ & $-0.240 *$ & -0.162 & -0.173 & $-0.217^{*}$ & -0.165 & -0.098 & -0.085 \\
\hline$A G$ & $-0.244^{*}$ & -0.170 & $-0.297 * *$ & $-0.250 * *$ & $-0.239 *$ & -0.081 & $-0.272 * *$ & $-0.255^{* *}$ & $-0.239 *$ & $-0.232 *$ & $-0.211 *$ & $-0.305^{* *}$ \\
\hline$P R$ & 0.163 & 0.110 & 0.139 & 0.139 & 0.203 * & 0.107 & 0.069 & 0.089 & 0.057 & 0.124 & 0.138 & 0.160 \\
\hline TC & 0.060 & 0.054 & -0.053 & -0.051 & -0.069 & 0.009 & -0.049 & 0.002 & 0.037 & 0.025 & -0.014 & -0.013 \\
\hline$L C$ & -0.042 & -0.058 & 0.047 & -0.079 & -0.035 & -0.020 & -0.034 & $-0.198 *$ & -0.062 & -0.156 & -0.070 & 0.067 \\
\hline$E X$ & $-0.241 *$ & -0.184 & -0.115 & $-0.256^{* *}$ & $-0.202 *$ & -0.084 & $-0.256^{* *}$ & $-0.262 * *$ & $-0.193^{*}$ & $-0.199 *$ & $-0.221 *$ & $-0.313^{* *}$ \\
\hline$K S$ & 0.120 & 0.099 & 0.080 & 0.072 & 0.106 & 0.139 & 0.042 & 0.059 & 0.015 & 0.085 & 0.094 & 0.127 \\
\hline
\end{tabular}

Source: Authors. $p$ value: ${ }^{* *}<0.05 ;{ }^{*}<0.10$. 
Table A3. Spearman correlation matrix: knowledge of information access and management tools.

\begin{tabular}{cccccccc}
\hline & INF01 & INF02 & INF03 & INF04 & INF05 & INF06 & INF07 \\
\hline$S X$ & -0.067 & -0.140 & $-0.220^{*}$ & $-0.219 *$ & $-0.256^{* *}$ & -0.125 & -0.174 \\
\hline$A G$ & -0.136 & $-0.232 *$ & $-0.285 *$ & -0.128 & -0.177 & $-0.229 *$ & -0.136 \\
\hline$P R$ & 0.172 & 0.006 & 0.128 & -0.007 & 0.131 & 0.093 & 0.074 \\
\hline$T C$ & 0.079 & 0.099 & -0.114 & -0.115 & -0.075 & -0.049 & -0.156 \\
\hline$L C$ & -0.062 & -0.007 & -0.123 & -0.106 & -0.099 & 0.085 & -0.042 \\
\hline$E X$ & -0.113 & -0.088 & $-0.201 *$ & $-0.270 * *$ & -0.096 & -0.170 & $-0.250 *$ \\
\hline$K S$ & 0.117 & 0.145 & 0.034 & $0.219 *$ & 0.028 & $0.213^{*}$ & -0.005 \\
\hline
\end{tabular}

Source: Authors. $p$-value: ${ }^{* *}<0.05 ;{ }^{*}<0.10$.

Table A4. (a,b) Spearman correlation matrix: knowledge of content creation tools.

\begin{tabular}{|c|c|c|c|c|c|c|c|c|}
\hline \multicolumn{9}{|c|}{ (a) } \\
\hline & СТT01 & СТT02 & СТT03 & СТT04 & СТT05 & СТT06 & СТT07 & СТT08 \\
\hline$S X$ & 0.081 & 0.028 & -0.169 & -0.165 & $\underset{*}{-0.202}$ & -0.108 & $-\underset{* *}{0.263}$ & -0.043 \\
\hline$A G$ & -0.128 & -0.165 & $\underset{* *}{-0.253}$ & $\underset{* *}{-0.269}$ & -0.159 & $\underset{*}{-0.210}$ & -0.197 & $-\underset{* *}{-0.281}$ \\
\hline$P R$ & $0.253 *$ & $0.271 * *$ & 0.156 & 0.057 & 0.111 & $0.248^{*}$ & 0.250 * & 0.239 * \\
\hline TC & 0.077 & 0.117 & 0.109 & 0.011 & 0.050 & -0.080 & -0.015 & -0.028 \\
\hline$L C$ & -0.097 & -0.170 & $\begin{array}{c}-0.239 \\
*\end{array}$ & -0.155 & -0.058 & -0.036 & 0.015 & 0.031 \\
\hline$E X$ & -0.162 & -0.160 & $\underset{*}{-0.206}$ & $\underset{*}{-0.216}$ & -0.160 & -0.163 & -0.160 & $-\underset{* *}{-0.296}$ \\
\hline$K S$ & 0.105 & 0.096 & 0.132 & $0.195 *$ & 0.034 & 0.077 & 0.109 & 0.082 \\
\hline \multicolumn{9}{|c|}{ (b) } \\
\hline & СTT09 & CTT10 & CTT11 & CTT12 & CTT13 & CTT14 & CTT15 & CTT16 \\
\hline$S X$ & -0.109 & -0.069 & $\begin{array}{c}-0.224 \\
*\end{array}$ & -0.002 & -0.162 & -0.161 & 0.007 & -0.131 \\
\hline$A G$ & -0.088 & -0.109 & -0.096 & $\underset{* *}{-0.278}$ & -0.205 & $-\underset{* *}{0.276}$ & $\begin{array}{c}-0.218 \\
*\end{array}$ & $\begin{array}{c}-0.229 \\
*\end{array}$ \\
\hline$P R$ & 0.057 & 0.099 & 0.120 & 0.194 & -0.015 & 0.062 & 0.137 & 0.126 \\
\hline$T C$ & -0.066 & -0.042 & -0.058 & -0.084 & -0.008 & -0.009 & -0.024 & -0.009 \\
\hline$L C$ & -0.024 & -0.018 & -0.039 & 0.006 & -0.158 & $\begin{array}{c}-0.204 \\
*\end{array}$ & -0.008 & -0.175 \\
\hline$E X$ & -0.137 & -0.110 & -0.082 & $\begin{array}{c}-0.284 \\
* *\end{array}$ & -0.199 & $\begin{array}{c}-0.238 \\
*\end{array}$ & $\begin{array}{c}-0.234 \\
*\end{array}$ & -0.168 \\
\hline$K S$ & 0.165 & -0.006 & 0.196 & 0.006 & -0.033 & 0.001 & 0.003 & -0.037 \\
\hline
\end{tabular}


Table A5. Spearman correlation matrix: knowledge of communication tools.

\begin{tabular}{|c|c|c|c|c|c|c|c|c|c|}
\hline & COM01 & COM02 & СОМ03 & COM04 & COM05 & СОМ06 & COM07 & COM08 & COM09 \\
\hline$S X$ & -0.083 & -0.011 & -0.087 & 0.015 & $-0.203^{*}$ & -0.090 & -0.184 & -0.098 & $-0.216^{*}$ \\
\hline$A G$ & -0.100 & $-0.230 *$ & -0.244 * & -0.175 & $-0.302 * *$ & $-0.286^{* *}$ & -0.172 & $-0.194 *$ & -0.244 * \\
\hline$P R$ & -0.011 & $0.213^{*}$ & 0.021 & 0.183 & 0.145 & 0.270 * & $0.255^{* *}$ & 0.059 & 0.135 \\
\hline$T C$ & 0.841 & 0.581 & 0.847 & 0.417 & 0.935 & 0.359 & 0.303 & 0.730 & 0.635 \\
\hline$L C$ & -0.002 & -0.055 & -0.132 & -0.046 & $-0.205^{*}$ & -0.052 & -0.028 & -0.084 & -0.074 \\
\hline$E X$ & -0.080 & -0.161 & $-0.230 *$ & -0.162 & $-0.261 * *$ & -0.126 & -0.097 & -0.151 & -0.218 * \\
\hline$K S$ & 0.163 & -0.021 & -0.006 & 0.070 & 0.085 & 0.067 & 0.158 & 0.048 & 0.073 \\
\hline
\end{tabular}

Source: Authors. $p$ value: ${ }^{* *}<0.05 ;{ }^{*}<0.10$.

Table A6. Spearman correlation matrix: knowledge of tools associated with safety.

\begin{tabular}{ccccccccc}
\hline & SAF01 & SAF02 & SAF03 & SAF04 & SAF05 & SAF06 & SAF07 & SAF08 \\
\hline$S X$ & -0.168 & -0.125 & $-0.200^{*}$ & $-0.239^{*}$ & -0.087 & $-0.222^{*}$ & -0.181 & -0.084 \\
\hline$A G$ & -0.174 & -0.145 & -0.137 & -0.109 & $-0.290^{* *}$ & $-0.220^{*}$ & -0.123 & $-0.260 *$ \\
\hline$P R$ & -0.117 & -0.026 & 0.145 & 0.043 & $0.014^{*}$ & 0.040 & $0.198^{*}$ & 0.125 \\
\hline$T C$ & -0.037 & -0.027 & 0.028 & 0.056 & -0.036 & -0.090 & -0.014 & -0.066 \\
\hline$L C$ & -0.161 & -0.004 & -0.161 & -0.077 & -0.092 & -0.184 & -0.062 & -0.061 \\
\hline$E X$ & $-0.204^{*}$ & -0.178 & -0.135 & -0.058 & $-0.265^{* *}$ & -0.188 & -0.135 & $-0.210^{*}$ \\
\hline$K S$ & 0.091 & 0.153 & 0.102 & 0.083 & 0.053 & 0.041 & 0.075 & 0.102 \\
\hline
\end{tabular}

Source: Authors. $p$ value: ${ }^{* *}<0.05 ;{ }^{*}<0.10$.

Table A7. Spearman correlation matrix: use of problem solving tools.

\begin{tabular}{|c|c|c|c|c|c|c|c|c|c|c|c|c|}
\hline & PST01 & PST02 & PST03 & PST04 & PST05 & PST06 & PST07 & PST08 & PST09 & PST10 & PST11 & PST12 \\
\hline$S X$ & -0.027 & $-\underset{*}{0.205}$ & 067 & -0.156 & $\underset{*}{-0.213}$ & $\begin{array}{c}-0.239 \\
*\end{array}$ & -0.129 & -0.176 & $\begin{array}{c}-0.248 \\
*\end{array}$ & -0.079 & -0.104 & -0.009 \\
\hline$A G$ & $\begin{array}{c}-0.294 \\
* *\end{array}$ & $\begin{array}{c}-0.213 \\
*\end{array}$ & -0.158 & $\begin{array}{c}-0.284 \\
* *\end{array}$ & $\begin{array}{c}-0.204 \\
*\end{array}$ & -0.051 & $\begin{array}{c}-0.305 \\
* *\end{array}$ & $\underset{*}{-0.203}$ & $\begin{array}{c}-0.202 \\
*\end{array}$ & -0.101 & -0.121 & $\underset{* *}{-0.322}$ \\
\hline$P R$ & 0.096 & 0.095 & 0.090 & 0.083 & 0.186 & 0.045 & 0.042 & 0.097 & 0.045 & 0.158 & 0.126 & 0.016 \\
\hline TC & 0.129 & 0.027 & -0.063 & -0.034 & -0.056 & -0.008 & -0.094 & 0.049 & 0.002 & -0.011 & -0.071 & -0.015 \\
\hline$L C$ & 0.004 & -0.077 & 0.063 & -0.034 & -0.042 & -0.021 & -0.082 & $\begin{array}{c}-0.208 \\
*\end{array}$ & -0.083 & -0.105 & -0.069 & 0.062 \\
\hline$E X$ & $-\underset{* *}{0.257}$ & $\begin{array}{c}-0.219 \\
*\end{array}$ & -0.028 & $\begin{array}{c}-0.237 \\
*\end{array}$ & -0.139 & -0.040 & $\begin{array}{c}-0.252 \\
* *\end{array}$ & -0.177 & -0.126 & -0.031 & -0.114 & $\begin{array}{c}-0.296 \\
*\end{array}$ \\
\hline$K S$ & 0.020 & 0.109 & -0.016 & 0.065 & 0.087 & 0.084 & 0.086 & -0.005 & -0.057 & 0.029 & 0.083 & 0.054 \\
\hline
\end{tabular}

Source: Authors. $p$ value: ${ }^{* *}<0.05 ;{ }^{*}<0.10$.

Table A8. Spearman correlation matrix: use of information access and management tools.

\begin{tabular}{cccccccc}
\hline & INF01 & INF02 & INF03 & INF04 & INF05 & INF06 & INF07 \\
\hline$S X$ & 0.005 & -0.136 & -0.068 & -0.090 & $-0.209 *$ & -0.084 & $-0.211^{*}$ \\
\hline$A G$ & -0.154 & -0.122 & -0.067 & $-0.319 * *$ & -0.069 & $-0.208 *$ & -0.146 \\
\hline$P R$ & 0.043 & -0.015 & 0.023 & -0.026 & 0.079 & 0.070 & -0.013 \\
\hline$T C$ & 0.073 & 0.049 & -0.029 & -0.148 & -0.097 & -0.090 & -0.199 \\
\hline
\end{tabular}


Table A8. Cont.

\begin{tabular}{cccccccc}
\hline & INF01 & INF02 & INF03 & INF04 & INF05 & INF06 & INF07 \\
\hline$L C$ & -0.089 & 0.010 & -0.099 & -0.082 & -0.123 & 0.049 & -0.085 \\
\hline$E X$ & -0.141 & -0.036 & -0.007 & $-0.223^{*}$ & -0.014 & -0.164 & -0.152 \\
\hline$K S$ & 0.058 & 0.099 & -0.060 & 0.115 & -0.096 & 0.124 & -0.100 \\
\hline
\end{tabular}

Source: Authors. $p$ value: ${ }^{* *}<0.05 ;{ }^{*}<0.10$.

Table A9. (a,b) Spearman correlation matrix.: use of content creation tools.

\begin{tabular}{|c|c|c|c|c|c|c|c|c|}
\hline \multicolumn{9}{|c|}{ (a) } \\
\hline & СТT01 & СТT02 & СТT03 & СТT04 & СТT05 & СТT06 & СТT07 & СТT08 \\
\hline$S X$ & 0.069 & 0.090 & -0.065 & -0.015 & -0.060 & -0.085 & -0.162 & -0.007 \\
\hline$A G$ & -0.050 & -0.117 & -0.122 & $-0.325^{* *}$ & $-0.212 *$ & -0.194 & -0.173 & $-0.296^{* *}$ \\
\hline$P R$ & $0.247^{*}$ & $0.270^{* *}$ & 0.012 & 0.037 & 0.013 & 0.078 & 0.000 & 0.106 \\
\hline$T C$ & 0.016 & 0.035 & 0.119 & 0.009 & -0.056 & -0.071 & 0.014 & -0.045 \\
\hline$L C$ & 0.000 & -0.076 & -0.193 & 0.011 & -0.011 & -0.002 & -0.135 & 0.087 \\
\hline$E X$ & -0.054 & -0.124 & -0.113 & $-0.237 *$ & $-0.226 *$ & -0.035 & -0.129 & -0.234 * \\
\hline$K S$ & 0.151 & 0.003 & -0.003 & 0.180 & -0.041 & 0.010 & 0.027 & 0.072 \\
\hline \multicolumn{9}{|c|}{ (b) } \\
\hline & СТT09 & CTT10 & CTT11 & CTT12 & СТT13 & CTT14 & CTT15 & CTT16 \\
\hline$S X$ & -0.016 & -0.052 & -0.171 & 0.020 & -0.060 & -0.098 & 0.084 & -0.076 \\
\hline$A G$ & -0.187 & $-0.193^{*}$ & -0.089 & $-0.267^{* *}$ & -0.177 & -0.164 & $-0.238^{*}$ & $-0.223 *$ \\
\hline$P R$ & 0.082 & 0.197 * & 0.122 & $0.267^{* *}$ & 0.012 & -0.009 & 0.013 & 0.072 \\
\hline TC & -0.070 & 0.000 & -0.119 & -0.135 & -0.099 & 0.034 & 0.030 & 0.052 \\
\hline$L C$ & -0.070 & -0.076 & -0.022 & 0.012 & -0.183 & -0.150 & -0.082 & $-0.196^{*}$ \\
\hline$E X$ & -0.170 & -0.109 & -0.064 & $-0.304^{* *}$ & -0.156 & -0.133 & $-0.246^{*}$ & -0.130 \\
\hline$K S$ & 0.137 & -0.026 & 0.224 * & 0.084 & -0.088 & 0.031 & 0.008 & -0.041 \\
\hline
\end{tabular}

Source: Authors. $p$ value: ${ }^{* *}<0.05 ;{ }^{*}<0.10$.

Table A10. Spearman correlation matrix: use of communication tools.

\begin{tabular}{cccccccccc}
\hline & COM01 & COM02 & COM03 & COM04 & COM05 & COM06 & COM07 & COM08 & COM09 \\
\hline$S X$ & -0.059 & -0.022 & 0.012 & 0.086 & -0.038 & -0.029 & -0.127 & 0.025 & $-0.221^{*}$ \\
\hline$A G$ & -0.180 & $-0.212^{*}$ & $-0.265^{* *}$ & -0.143 & $-0.339^{* *}$ & $-0.246^{*}$ & -0.188 & -0.195 & $-0.269^{* *}$ \\
\hline$P R$ & -0.022 & $0.259^{* *}$ & 0.043 & $0.200^{*}$ & 0.034 & $0.216^{*}$ & $0.272^{* *}$ & -0.012 & 0.124 \\
\hline$T C$ & -0.044 & 0.075 & 0.043 & -0.144 & -0.122 & -0.183 & -0.112 & -0.045 & -0.046 \\
\hline$L C$ & 0.021 & -0.071 & -0.140 & -0.058 & -0.027 & -0.020 & -0.004 & -0.001 & -0.111 \\
\hline$E X$ & -0.076 & -0.181 & $-0.189 *$ & -0.120 & $-0.225^{*}$ & -0.039 & -0.121 & -0.138 & $-0.219 *$ \\
\hline$K S$ & 0.120 & -0.055 & 0.019 & -0.007 & 0.132 & -0.078 & 0.139 & 0.157 & -0.002 \\
\hline
\end{tabular}

Source: Authors. $p$ value: ${ }^{* *}<0.05 ;{ }^{*}<0.10$.

Table A11. Spearman correlation matrix: use of tools associated with safety.

\begin{tabular}{ccccccccc}
\hline & SAF01 & SAF02 & SAF03 & SAF04 & SAF05 & SAF06 & SAF07 & SAF08 \\
\hline$S X$ & -0.112 & -0.015 & -0.154 & -0.186 & -0.015 & -0.155 & -0.138 & 0.026 \\
\hline$A G$ & $-0.238^{*}$ & -0.140 & -0.130 & -0.117 & $-0.322^{* *}$ & $-0.220^{*}$ & -0.094 & $-0.274^{* *}$ \\
\hline
\end{tabular}


Table A11. Cont.

\begin{tabular}{ccccccccc}
\hline & SAF01 & SAF02 & SAF03 & SAF04 & SAF05 & SAF06 & SAF07 & SAF08 \\
\hline$P R$ & 0.120 & 0.023 & -0.077 & 0.012 & 0.086 & 0.101 & 0.150 & 0.058 \\
\hline$T C$ & 0.027 & -0.062 & -0.005 & 0.025 & -0.042 & -0.040 & -0.079 & -0.143 \\
\hline$L C$ & -0.154 & -0.032 & -0.092 & -0.047 & -0.100 & -0.195 & -0.101 & -0.010 \\
\hline$E X$ & $-0.200 *$ & -0.156 & -0.102 & -0.036 & $-0.259 * *$ & -0.154 & -0.089 & -0.196 \\
\hline$K S$ & 0.046 & 0.012 & 0.106 & -0.041 & -0.001 & 0.037 & -0.016 & 0.060 \\
\hline & & Source: Authors. $p$ value: ${ }^{* *}<0.05{ }^{*}<0.10$. &
\end{tabular}

\section{Appendix C. ANOVA Analysis. Item Groups}

Table A12. ANOVA: knowledge and use of problem solving tools.

\begin{tabular}{ccccc}
\hline & \multicolumn{2}{c}{ Knowledge } & \multicolumn{2}{c}{ Use } \\
\hline PTS01 & F & Sig. & F & Sig. \\
\hline PTS02 & 97.096 & 0.000 & 48.682 & 0.000 \\
\hline PTS03 & 210.564 & 0.000 & 218.669 & 0.000 \\
\hline PTS04 & 46.507 & 0.000 & 21.204 & 0.000 \\
\hline PTS05 & 108.251 & 0.000 & 65.930 & 0.000 \\
\hline PTS06 & 221.553 & 0.000 & 146.953 & 0.000 \\
\hline PTS07 & 97.096 & 0.000 & 78.486 & 0.000 \\
\hline PTS08 & 147.921 & 0.000 & 113.016 & 0.000 \\
\hline PTS09 & 84.497 & 0.000 & 73.749 & 0.000 \\
\hline PTS10 & 168.998 & 0.000 & 147.707 & 0.000 \\
\hline PTS11 & 184.238 & 0.000 & 131.365 & 0.000 \\
\hline PTS12 & 92.517 & 0.000 & 65.334 & 0.000 \\
\hline
\end{tabular}

Table A13. ANOVA: knowledge and use of information access and management tools.

\begin{tabular}{ccccc}
\hline & \multicolumn{2}{c}{ Knowledge } & \multicolumn{2}{c}{ Use } \\
\hline & F & Sig. & F & Sig. \\
\hline INF01 & 57.999 & 0.000 & 31.291 & 0.000 \\
\hline INF02 & 72.283 & 0.000 & 105.877 & 0.000 \\
\hline INF03 & 70.939 & 0.000 & 47.377 & 0.000 \\
\hline INF04 & 124.521 & 0.000 & 61.635 & 0.000 \\
\hline INF05 & 118.445 & 0.000 & 81.863 & 0.000 \\
\hline INF06 & 52.390 & 0.000 & 38.640 & 0.000 \\
\hline INF07 & 83.777 & 0.000 & 54.344 & 0.000 \\
\hline
\end{tabular}


Table A14. ANOVA: knowledge and use of content creation tools.

\begin{tabular}{|c|c|c|c|c|}
\hline & \multicolumn{2}{|c|}{ Knowledge } & \multicolumn{2}{|c|}{ Use } \\
\hline & $F$ & Sig. & F & Sig. \\
\hline CCT1 & 21.363 & 0.000 & 11.985 & 0.001 \\
\hline ССT2 & 48.748 & 0.000 & 15.043 & 0.000 \\
\hline ССТ3 & 117.474 & 0.000 & 99.810 & 0.000 \\
\hline CCT4 & 104.470 & 0.000 & 37.652 & 0.000 \\
\hline CCT5 & 47.164 & 0.000 & 30.868 & 0.000 \\
\hline СCT6 & 150.648 & 0.000 & 109.603 & 0.000 \\
\hline CCT7 & 129.873 & 0.000 & 87.192 & 0.000 \\
\hline ССТ8 & 183.080 & 0.000 & 69.662 & 0.000 \\
\hline ССТ9 & 72.719 & 0.000 & 68.353 & 0.000 \\
\hline CCT10 & 159.399 & 0.000 & 76.025 & 0.000 \\
\hline CCT11 & 40.547 & 0.000 & 22.422 & 0.000 \\
\hline ССТ12 & 80.794 & 0.000 & 47.802 & 0.000 \\
\hline CCT13 & 71.961 & 0.000 & 69.206 & 0.000 \\
\hline CCT14 & 85.265 & 0.000 & 45.680 & 0.000 \\
\hline CCT15 & 53.892 & 0.000 & 34.584 & 0.000 \\
\hline CCT16 & 78.793 & 0.000 & 61.402 & 0.000 \\
\hline
\end{tabular}

Table A15. ANOVA: knowledge and use of communication tools.

\begin{tabular}{ccccc}
\hline & \multicolumn{2}{c}{ Knowledge } & \multicolumn{2}{c}{ Use } \\
\hline & F & Sig. & F & Sig. \\
\hline COM01 & 66.822 & 0.000 & 34.753 & 0.000 \\
\hline COM02 & 107.851 & 0.000 & 42.058 & 0.000 \\
\hline COM03 & 98.715 & 0.000 & 46.417 & 0.000 \\
\hline COM04 & 85.915 & 0.000 & 55.813 & 0.000 \\
\hline COM05 & 142.526 & 0.000 & 42.795 & 0.000 \\
\hline COM06 & 61.545 & 0.000 & 25.989 & 0.000 \\
\hline COM07 & 76.639 & 0.000 & 52.433 & 0.000 \\
\hline COM08 & 143.110 & 0.000 & 88.206 & 0.000 \\
\hline COM09 & 189.556 & 0.000 & 49.947 & 0.000 \\
\hline
\end{tabular}

Table A16. ANOVA: knowledge and use of safety tools.

\begin{tabular}{ccccc}
\hline & \multicolumn{2}{c}{ Knowledge } & \multicolumn{2}{c}{ Use } \\
\hline & F & Sig. & F & Sig. \\
\hline SAF01 & 86.101 & 0.000 & 81.735 & 0.000 \\
\hline SAF02 & 58.112 & 0.000 & 27.516 & 0.000 \\
\hline SAF03 & 266.285 & 0.000 & 174.341 & 0.000 \\
\hline SAF04 & 111.217 & 0.000 & 108.158 & 0.000 \\
\hline
\end{tabular}


Table A16. Cont.

\begin{tabular}{ccccc}
\hline & \multicolumn{2}{c}{ Knowledge } & \multicolumn{2}{c}{ Use } \\
\hline & F & Sig. & F & Sig. \\
\hline SAF05 & 122.915 & 0.000 & 82.059 & 0.000 \\
\hline SAF06 & 105.161 & 0.000 & 79.911 & 0.000 \\
\hline SAF07 & 55.572 & 0.000 & 41.515 & 0.000 \\
\hline SAF08 & 96.470 & 0.000 & 52.658 & 0.000 \\
\hline
\end{tabular}

\section{References}

1. López-Gil, M.; Bernal, C. El perfil del profesorado en la Sociedad Red: Reflexiones sobre las competencias digitales de los y las estudiantes en Educación de la Universidad de Cádiz. Int. J. Ed. Res. Innov. 2019, 11, 83-100.

2. Sabater, C.; Martínez, I.; Santiago, R. La Tecnosocialidad: El papel de las TIC en las relaciones sociales. Rev. Lat. Comun. Soc. 2017, $72,1592-1607$.

3. Udemy for Business. 2020 Workplace Learning Trends Report: The Skills of the Future; Udemy for BUSINESS: San Francisco, CA, USA, 2020; Available online: https:/ / business.udemy.com/resources/5-workplace-learning-trends-2020/ (accessed on 6 July 2020).

4. Scherer, R.; Siddiq, F.; Tondeur, J. The technology acceptance model (TAM): A meta-analytic structural equation modeling approach to explaining teachers' adoption of digital technology in education. Comp. Edu. 2019, 128, 13-35. [CrossRef]

5. Colás, M.P.; de Pablos, J.; Ballesta, J. Incidencia de las TIC en la enseñanza en el sistema educativo español: Una revisión de la investigación. Rev. Edu. Dist. 2018, 18,1-23. [CrossRef]

6. Siddiq, F.; Hatlevik, O.E.; Olsen, R.V.; Throndsen, I.; Scherer, R. Taking a future perspective by learning from the past-A systematic review of assessment instruments that aim to measure primary and secondary school students' ICT literacy. Edu. Res. Rev. 2016, 19, 58-84. [CrossRef]

7. Romero-Tena, R.; Llorente-Cejudo, C.; Puig-Gutiérrez, M.; Barragán-Sánchez, R. The Pandemic and Changes in the Self-Perception of Teacher Digital Competences of Infant Grade Students: A Cross Sectional Study. Int. J. Environ. Res. Public Health 2021, 18, 4756. [CrossRef]

8. Álvarez, J.F. La Formación en TIC del profesorado de Secundaria del Estado Español. Un análisis desde la percepción docente. Universitas Tarraconensis. Rev. De Ciències De L'educació 2016, 1, 67-79.

9. Fernández, J.M.; Reyes, M.M.; El Homrani, M. TIC y discapacidad. Principales barreras para la formación del profesorado. EDMETIC Rev. De Educ. Mediática Y TIC 2018, 7, 1-25. [CrossRef]

10. Krumsvik, R. Situated learning in the network society and the digitised school. Eur. J. Teach. Edu. 2009, 32, 167-185. [CrossRef]

11. Krauskopf, K.; Foulger, T.S.; Williams, M.K. Prompting teachers' reflection of their professional knowledge. A proof-of-concept study of the Graphic Assessment of TPACK Instrument. Teach. Dev. 2018, 22, 153-174. [CrossRef]

12. Kampylis, P.; Punie, Y.; Devine, J. Promoting Effective Digital-Age Learning-A European Framework for Digitally Competent Educational Organisations; JRC Publications Repository. EUR 27599 EN; Publications Office of the European Union: Luxembourg, 2015.

13. Perrotta, C.; Gulson, K.N.; Williamson, B.; Witzenberger, K. Automation, APIs and the distributed labour of platform pedagogies in Google Classroom. Crit. Stud. Educ. 2021, 62, 97-113. [CrossRef]

14. Carrillo, C.; Flores, M.A. COVID-19 and teacher education: A literature review of online teaching and learning practices. Eur. J. Teach. Educ. 2020, 43, 466-487. [CrossRef]

15. Shah, S.S.; Shah, A.A.; Memon, F.; Kemal, A.A.; Soomro, A. Online learning during the COVID-19 pandemic: Applying the self-determination theory in the 'new normal'. Rev. Psicodidact. 2021, in press.

16. National Institute of Educational Technologies and Teacher Training, NIETTT. Marco Común de Competencia Digital Docente. 2017. Available online: https://aprende.intef.es/sites/default/files/2018-05/2017_1020_Marco-Com\%C3\%BAn-deCompetencia-Digital-Docente.pdf (accessed on 1 July 2020).

17. Usart, M.; Lázaro, J.L.; Gisbert, M. Validation of a tool for self-evaluating teacher digital competence. Education XX1 2021, $24,353-373$.

18. Comisión Europea. Recomendación 2006/962/CE del Parlamento Europeo y del Consejo de 18 de Diciembre de 2006 Sobre Las Competencias Clave Para el Aprendizaje Permanente. 2006. Available online: https://www.boe.es/buscar/doc.php?id=DOUEL-2006-82748 (accessed on 1 July 2020).

19. Moreno, T. Competencias en educación. Una mirada crítica. Rev. Mex. Inv. Educ. 2010, 15, 289-297.

20. Organización Para la Cooperación y el Desarrollo Económico, OCDE. Definición y Selección de Competencias Clave. Resumen Ejecutivo. Available online: http://comclave.educarex.es/pluginfile.php/130/mod_resource/content/3/DESECO.pdf (accessed on 1 July 2020).

21. Paredes, J.; Guitert, M.; Rubia, B. La innovación y la tecnología educativa como base de la formación inicial del profesorado para la renovación de la enseñanza. Rev. Lat. Tec. Educ. 2015, 14, 101-114.

22. Pavié, A. Formación docente: Hacia una definición del concepto de competencia profesional docente. Rev. Elec. Interuniv. Prof. 2011, 14, 67-80. 
23. Sánchez-Antolín, P. La concreción de las políticas educativas de integración de las TIC europeas y españolas en la comunidad de Madrid. Educ. Knowl. Soc. 2014, 15, 107-133. [CrossRef]

24. Castañeda, L.; Esteve, F.; Adell, J. ¿Por qué es necesario repensar la competencia docente para el mundo digital? RED. Rev. Educ. Dist. 2018, 56, 31-32.

25. Cabero-Almenara, J.; Palacios-Rodríguez, A. Marco Europeo de Competencia Digital Docente «DigCompEdu». Traducción y adaptación del cuestionario «DigCompEdu Check-In». EDMETIC 2020, 9, 213-234. [CrossRef]

26. Koehler, M.; Mishra, P. What is technological pedagogical content knowledge (TPACK)? Contemp. Issues Technol. Teach. Educ. 2009, 9, 60-70. [CrossRef]

27. Alonso, A. El desarrollo del concepto de competencia digital en el currículum de las enseñanzas obligatorias de Galicia. Innov. Educ. 2011, 21, 151-159.

28. Cejas, R.; Navío, A.; Barroso, J. Las competencias del profesorado universitario desde el modelo TPACK (Conocimiento Tecnológico y Pedagógico del Contenido). Píxel-Bit Rev. Med. Educ. 2016, 49, 105-119.

29. Castro, S.; Guzmán, B.; Casado, D. Las TIC en los procesos de enseñanza y aprendizaje. Laurus 2007, 13, $213-234$.

30. Huertas, A.; Pantoja, A. Efectos de un programa educativo basado en el uso de las TIC sobre el rendimiento académico y la motivación del alumnado en la asignatura de tecnología de educación secundaria. Education XX1 2016, 19, 229-250. [CrossRef]

31. Miralles, P.; Gómez, C.J.; Monteagudo, J. Perceptions on the use of ICT resources and mass-media for the teaching of History. A comparative study among future teachers of Spain-England. Education XX1 2019, 22, 187-211.

32. Fernández, J.C.; Fernández, M.C.; Cebreiro, B. Desarrollo de un cuestionario de competencias en TIC para profesores de distintos niveles educativos. Píxel-Bit Rev. Med. Educ. 2016, 48, 135-148.

33. Falcó, J.M. Evaluación de la competencia digital docente en la comunidad autónoma de Aragón. Rev. Elec. Inv. Educ. 2017, 19, 73-83.

34. Fernández-Cruz, F.J.; Fernández-Díaz, M.J.; Rodríguez-Mantilla, J.M. Design, and validation of an instrument to measure teacher training profiles in information and communication technologies. Rev. Esp. Ped. 2018, 76, 247-270.

35. Cervera, M.G.; Cantabrana, J.L. Professional development in teacher digital competence and improving school quality from the teachers' perspective: A case study. J. N. Appr. Edu. Res. 2015, 4, 115-122. [CrossRef]

36. Sanabria, A.; Cepeda, O. La educación para la competencia digital en los centros escolares: La ciudadanía digital. Rev. Lat. Tec. Educ. 2016, 15, 95-112.

37. Tourón, J.; Martín, D.; Navarro, E.; Pradas, S.; Iñigo, V. Validación de constructo de un instrumento para medir la competencia digital docente de los profesores. Rev. Esp. Ped. 2018, 76, 25-54. [CrossRef]

38. Valdivieso, T.S.; Gonzáles, M.Á. Competencia Digital Docente: ¿Dónde Estamos? Perfil del Docente de Educación Primaria y Secundaria. El Caso de Ecuador. Píxel-Bit Rev. Med. Educ. 2016, 49, 57-73.

39. Gisbert, M.; González, J.; Esteve, F.M. Competencia digital y competencia digital docente: Una panorámica sobre el estado de la cuestión. Rev. Interuniv. Inv. Tec. Educ. 2016, 74-83. [CrossRef]

40. Daniel, J. Education, and the COVID-19 pandemic. Prospects 2020, 49, 91-96. [CrossRef]

41. Batubara, B.M. The Problems of the World of Education in the Middle of the Covid-19 Pandemic. Hum. Soc. Sci. 2021, 4, 450-457.

42. Fuentes, A.; López, J.; Pozo, S. Análisis de la Competencia Digital Docente: Factor Clave en el Desempeño de Pedagogías Activas con Realidad Aumentada. Rev. Iberoam. Cal. Ef. Cam. Educ. 2019, 17, 27-42. [CrossRef]

43. Redecker, C. Marco Europeo Para la Competencia Digital de Los Educadores: DigCompEdu; (Trad. Fundación Universia y Ministerio de Educación y Formación Profesional de España); Secretaría General Técnica del Ministerio de Educación y Formación Profesional de España: Madrid, Spain, 2020.

44. Ting, D.S.W.; Carin, L.; Dzau, V.; Wong, T.Y. Digital technology, and COVID-19. Nat. Med. 2020, 26, 459-461. [CrossRef]

45. Williamson, B.; Eynon, R.; Potter, J. Pandemic politics, pedagogies, and practices: Digital technologies and distance education during the coronavirus emergency. Learn. Media Technol. 2020, 45, 107-114. [CrossRef]

46. García-Pérez, R.; Rebollo-Catalán, A.; García-Pérez, C. Relación entre las preferencias de formación del profesorado y su competencia digital en las redes sociales. Bordon 2016, 68, 137-153. [CrossRef]

47. Romero, S.; Hernández, C.; Ordóñez, X. La competencia digital de los docentes en educación primaria: Análisis cuantitativo de su competencia, uso y actitud hacia las nuevas tecnologías en la práctica docente. Rev. Tec. Cienc. Educ. 2016, 4, 33-51.

48. Gudmundsdottir, G.B.; Hatlevik, O.E. Newly qualified teachers' professional digital competence: Implications for teacher education. Eur. J. Teach. Educ. 2018, 41, 214-231. [CrossRef]

49. Sigalés, C.; Mominó, J.M.; Meneses, J.; Badia, A. La Integración de Internet en la Educación Escolar Española: Situación Actual y Perspectivas de Futuro Informe de Investigación; Ariel: Madrid, Spain, 2009.

50. Pozo, S.; López, J.; Fernández, M.; López, J.A. Análisis correlacional de los factores incidentes en el nivel de competencia digital del profesorado. Rev. Elec. Interuniv. Form. Prof. 2020, 23, 143-159.

51. Cejas-León, R.; Gámez, A.N. Formación en TIC del profesorado universitario. Factores que influyen en la transferencia a la función docente. Prof. Rev. Curríc. Form. Prof. 2018, 22, 271-293. [CrossRef]

52. Khachaturyan, N. Emotional burnout of teachers in the context of the transition to distance learning. XIV International Scientific and Practical Conference "State and Prospects for the Development of Agribusiness-INTERAGROMASH 2021". EDP Sci. E3S Web Conf. 2021, 273, 12043. [CrossRef] 
53. Daumiller, M.; Rinas, R.; Hein, J.; Janke, S.; Dickhäuser, O.; Dresel, M. Shifting from face-to-face to online teaching during COVID-19: The role of university faculty achievement goals for attitudes towards this sudden change, and their relevance for burnout/engagement and student evaluations of teaching quality. Comput. Hum. Behav. 2021, 118, 106677. [CrossRef]

54. Sailer, M.; Florian, S.-P.; Frank, F. Contextual facilitators for learning activities involving technology in higher education: The Cb-model. Comput. Hum. Behav. 2021, 121, 106794. [CrossRef] 